\title{
Venenum, Virus, Fear, and Politics
}

\author{
Zvi Bekerman $\mathbb{D}$
}

Received: 3 May 2020 / Accepted: 10 September 2020

(C) Journal of Bioethical Inquiry Pty Ltd. 2020

\begin{abstract}
This article presents a short reflection on the confluence between politics and pandemics as they are reflected in Israel in March and April 2020.
\end{abstract}

Keywords COVID-19 · Venum · Fear · Politics · Israel

On March 1, I flew from Tel Aviv to Santiago de Chile to participate in a doctoral defence. I was happy not to participate in a third round of the Israeli elections, well knowing that what I felt was right had no chance. I was sorry I was not able to negotiate having the defence two weeks earlier, for if successful I would have missed two weeks of heated political propaganda which mostly exposed the emptiness of present Zionist ideology and its racist undertones.

At the time, we had heard of the coronavirus outbreak in Wuhan, but it was well before the great dangers of the pandemic were declared or home confinement was talked about. Upon my return on March 13, I selfconfined to my home according to the newly published governmental guidelines, where I am still confined today, April 14 this time according to official decreeswhen writing this short note.

A colleague made the request to write something about the coronavirus as I experience it in Israel. I was not happy with the request, but though having the choice

Z. Bekerman $(\bowtie)$

The Seymour Fox School of Education, The Hebrew University of Jerusalem, 91905 Jerusalem, Israel

e-mail: zvi.bekerman@mail.huji.ac.il to say no, I found it difficult to refuse. I will set my own limitations, I thought. I will offer no broad reflections, not any summarizing or concluding thoughts. I am old enough to know that things are other than they seem; that is why we can get ourselves into trouble by jumping to conclusions. Seneca suggests we should always allow some time to elapse, for time discloses the truth: dandum semper est tempus: veritatem dies aperit. ${ }^{1}$

Some of my colleagues are not as careful, and I have already confronted a couple of them for having publicly decreed that the coronavirus event exposes the bankruptcy of neoliberal economics. They are not stupid; they know as well as I do that exercising good judgement means delaying it, for indeed truth is slow to make its appearance - if ever it does; and yet like many other academics they often succumb to narcissism (as I do now writing this short note).

Coronavirus seems to have taken us all by surprise and spoiled our judgement. In a very short time the world closed up as if paralyzed - and by what? A little parasite, egoistic enough to want to survive!

I was home with my spouse for the Pesach Seder (the ceremonial meal on the first day of Passover). We were alone this time - each family was alone, in compliance with the emergency measures set by the government to cope with the contagious virus. The news announced that both the prime minister and the president of Israel had violated government rules and conducted the Seder in the company of more than just the immediate family living with them-Matthew 23:2-4, without its possible

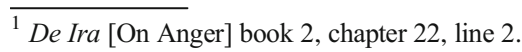


anti-Semitic undertones, comes to mind here. In Pesach, Jews commemorate the exodus of the children of Israel from Egypt; in a sense, Pesach is the festival of freedom. For Zionists, however, Passover carries added meanings. The early Zionist emphasis on issues of social justice and respect for the lot of the oppressed is being neglected ("passed-over") and its place has been taken by a strong emphasis on national (Jewish) freedom.

National Jewish freedom is to my ears as paradoxical as a "Jewish and democratic state," which in turn is as paradoxical as a festival of freedom and liberation celebrated while imprisoned in your house apart from your loved ones. I should not blame the government for this, because they are trying hard, under strenuous conditions, to safeguard the lives of all citizens (maybe not all: as per today a third of the virus casualties comes from retirement homes which have not been tested nor taken care off). Yet I cannot but wonder about the potential future influence of behaviours (decrees) which normalize what in other times would be considered totalitarian measures. On March 18, the government unanimously approved emergency regulations for gathering cell phone location data and additional personal information about those diagnosed with the coronavirus or those suspected of having been infected. The measures were justified by the need to enforce quarantine orders. The cabinet approved the measures through a special telephone survey and bypassed the Knesset. Some limitations on the Shin Bet activities were imposed, and the Shin Bet and the cell phone surveillance will exclude the content of conversations and messages. Soldiers (with only the officers armed) regularly patrol and help maintain the lockdown on cities and particular neighbourhoods. Here, Bertrand Russell comes to mind: "Neither a man, nor a crowd, nor a nation can be trusted to act humanely or to think sanely under the influence of a great fear" ([1943] 1995, 121).

The general public was indeed in fear, and for good reasons. The virus had suddenly appeared by surprise and without reason. The public saw the crisis unfolding through the TV news, which now occupied most of the broadcast schedule. It had taken the place of reality programmes and soap operas, like them, endlessly repetitious and adding little to the already known, yet creating more fear. We all learned daily about the number of infected, those that had died, and the ones who were getting better. We became specialists on "exponential growth," on "flattening curves," on masks, on "acute respiratory distress syndrome," and on the never- ending increase of jobless claims (over $25 \%$ of the population had lost their jobs).

There are good reasons to believe coronavirus is not partisan, not political, and not ideological. Yet it can turn into all of them when manipulated by a political genius (as in evil genius); indeed, our prime minister is exactly such a genius. He will never let a good crisis go without using it to increase his power, through innuendos reminiscent of (Jewish) nationalistic rhetoric. He quickly became a paternal figure, a Papa Doc - as in Francois "Doc" Duvalier. He offered himself as a totem to comfort the citizenry; he became the teacher who offered advice on how to wash our hands to prevent contagion and declared the need, given the coronavirus emergency, to create an emergency government. He spoke in general terms and made grand promises; it sounded as if the main goal of Papa's talk was to allow for him, when and if necessary, to wash his hands.

The greatest achievement of coronavirus, one for which we cannot just blame the prime minister, was that the right and so-called centre political parties reached the conclusion that an emergency government was needed to handle the national crisis created by the pandemic. Just before this happened, our justice minister announced that non-urgent court activity would be frozen, an announcement which miraculously resulted in the postponement of the corruption trial of our prime minister from March 17 to May 24 (just showing that coronavirus can be fatal to both humans and democracy).

After the elections, the leader of Blue and White, the so called centrist and liberal political alliance, received the endorsement of sixty-one members of the Knesset to form a new government. Though practically possible, politically it turned out to be impossible. Blue and White echoes the same racist rhetoric which the Likud has used for the last ten to fifteen years. According to this rhetoric, a true patriotic government cannot include any of the Arab parties in Israel (all of which are united today under the United List). Israel needs to stay a "Jewish and democratic state," and the coronavirus allowed this to be said openly and without regret. The leader of the Blue and White party betrayed the promises made before the elections never to serve under an indicted prime minister. The Labor party, which ran in the elections with Meretz (the only leftist Zionist party left in Israel), followed the Blue and White path. Both betrayed their electorate and their promises and justified their betrayal on the "new urgent needs" created by the pandemic. 
Coronavirus seems not to be able to change political behaviours: it just helps justify them. The negotiations have not come to fruition yet, and we seem to be reaching the end of the coronavirus crisis; if a coalition government is not formed, Papa will have once again successfully kept to his power, this time not only by deploying exclusionary and racially-tinged political rhetoric but with the help of a virus.

Coronavirus is said to be "universal," "cosmopolitan" (it recognizes no borders), and "blind" (it recognizes no human differences, constructed or real). This might be true about the virus, but the virus can actually do little all by itself. Rather, it sustains a dialogue with the circumstances, and together they both create what we call "realities." The reality created by the virus is not new. The rich are potential victims, but the poor are more certain, actual ones. In our present social sciences, poverty hides behind ethnicity, culture, and other essentialized categories, which are set as properties of individuals. The poor in Israel are many, but most are Arab/Palestinian and ultraOrthodox Jews, both citizens of Israel. Bnei Brak, an ultra-Orthodox city of about two hundred thousand neighbouring Tel-Aviv counted, by mid-April, 1,218 infected inhabitants, just $7 \%$ fewer than Jerusalem's count - out of a population of almost one million. In Jerusalem, the majority of coronavirus victims are concentrated in the ultra-Orthodox neighbourhoods of the city. Poor they are, but in news reports and in the media they are called ultra-Orthodox (Jaffe-Hoffman 2020). Ultra-Orthodox leaders signal their dissatisfaction when hearing these reports. They feel the ultra-Orthodox are being blamed for our Papa's flawed handling of the crisis. The news media, they say, are focusing on the ultraOrthodox rather than on the shortage of test kits, protective equipment, and respirators. This is not the first time in history that a disease has become a metaphor for evil. Syphilis became a standard trope in late nineteenth- and early twentieth-century anti-Semitic polemics (Sontag 2001), so there is no reason to expect that coronavirus could not become the same in the Israeli "Jewish and democratic state."

According to a recent National Insurance Institute of Israel annual poverty report, Arab Palestinian families living within the internationally recognized borders of Israel, which comprise $15 \%$ of families in Israel, represented $37.4 \%$ of poor families in Israel (Gal and Madhala 2017). Arab Palestinian Israelis fight coronavirus as doctors and nurses or health assistants; they are $20 \%$ of Israel's population and account for $17 \%$ of the country's doctors, but their political parties are not thought of as legitimate to be included in the coalition negotiations. They are first-class participants in the medical professions and the struggle against coronavirus but second-class citizens whose towns are allocated a disturbing lower number of coronavirus tests than the ones allocated to Jewish areas.

As for the conquered territories, or those supposedly under the governance of the Palestinian Authority (and/or Hamas), coronavirus might help make obsolete any dreams (nightmares) of a two-state solution. Coronavirus recognizes no artificial borders and forces all to be aware of the undeniable interdependence of all territories. As things stand, today coronavirus might contribute to an understanding that a one state for all citizens' solution is the only realistic option. This has the potential of freeing Zionism from its colonial undertones as much as strengthening the possibilities for an apartheid state.

Lastly, a footnote on education. What researchers and policymakers were not able to deliver through "hard" academic and or political work, the coronavirus pandemic has delivered with ease. Just a reminder that change is rather easy when and if needed by all, not just those wishing to impose it. "New technologies" in education, long heralded as the game changer in transforming our schools into institutions that can turn out students able to compete in the twenty-first century, were deployed from mid-March when classes were suspended in all schools and universities. The step was in general welcomed and for the most part successfully implemented. The success has been only diminished by the fact that the government and the teacher associations have not reached an agreement regarding the potential impact of the changes on teachers' contracts, by the fact the Ministry of Education opened a comprehensive educational portal for students in the Hebrew language but made far less material available in Arabic, and by the fact that Bedouin pupils are practically cut off from the programme altogether by lack of computer resources and electric power in their villages. Here, it is worthwhile to remember that the Bedouins are the poorest and most marginalized minority in Israel.

I believe change is possible, but I fail to understand why anyone would believe it is easy. A solution for coronavirus will be found, and humanity will learn to live with it, but much more than a virus, which can be tamed, is needed for genuine change to take place. These might not be good times for comfort, and sadly, politicians will endure, and our troubles with them. 


\section{References}

Gal, J., and S. Madhala. 2017. Developments in Israeli social welfare policy. In State of the nation report: Society economy and policy in Israel 2017, edited by A. Weiss, 155-168. Taub Center for Social Policy Studies in Israel.

Jaffe-Hoffman, M. 2020. Coronavirus by the numbers: Which Israeli cities have the most sick? The Jerusalem Post, March 31.
Russell, B. (1943) 1995. An outline of intellectual rubbish, in Unpopular Essays, by B. Russell. Revised ed. 1995. New York: Routledge.

Sontag, S., 2001. Illness as metaphor and AIDS and its metaphors. Macmillan.

Publisher's note Springer Nature remains neutral with regard to jurisdictional claims in published maps and institutional affiliations. 